\title{
Challenges of Implementing Restorative Justice for Intimate Partner Violence: An
}

\section{Islamic Perspective}

Md. Jahirul Islam ${ }^{1,2}{ }^{*}$; Masahiro Suzuki ${ }^{1}$; Nurunnahar Mazumder ${ }^{3}$; and Nada Ibrahim ${ }^{4}$

${ }^{1}$ School of Criminology and Criminal Justice, Griffith University, Brisbane, Australia

${ }^{2}$ Ministry of Planning, Bangladesh Planning Commission, Dhaka-1207, Bangladesh

${ }^{3}$ Department of Law, Jagannath University, Dhaka, Bangladesh

${ }^{4}$ Centre for Islamic Thought and Education, University of South Australia, Adelaide, South Australia, Australia

\section{Corresponding author}

Name: Md. Jahirul Islam, PhD

Affiliation: School of Criminology and Criminal Justice, Griffith University, 176 Messines

Ridge Road, Mt Gravatt, Queensland 4122, Australia

Tel: +61 (0)737351202

Email: mdjahirul.islam@griffithuni.edu.au

Accepted in Journal of Religion \& Spirituality in Social Work. 


\section{Abstract}

Intimate partner violence (IPV) is currently recognized as a critical public health concern and a human rights issue. Not surprisingly, Muslims - a religiously and socio-culturally diverse faith-based populace - are not an exception. To address this complex area of criminal justice and social policy, some scholars advocate implementing restorative justice (RJ) approaches. While RJ approaches have been traditionally used in Islamic cultures for conflict resolutions, to date, few studies have investigated how RJ operates in dealing with IPV in Muslim countries and communities. This article explores how RJ approaches towards IPV operate in some Muslim countries/communities, and offers insights into developing culturally and religiously appropriate ways of implementing RJ in IPV situations among Muslims. Given the prevalence of IPV among Muslims, the question is particularly important and timely. Taking exclusively limited examples of RJ approaches that have been used to mediate IPV cases in Muslim countries and communities, this paper found one significant challenge in the RJ approaches among Muslims: inappropriate norms/understandings about IPV. To reduce IPV in Muslim society, it is necessary to develop treatment models and techniques that meet cultural and religious needs. This paper found that since RJ is not alien to Islamic teachings, RJ approaches can be implemented effectively in dealing with IPV among Muslims by ensuring justice and equity of the abused woman. The findings of this paper will assist policymakers, practitioners, and service providers in providing religiously and culturally appropriate care when addressing IPV issues among Muslims.

\section{Keywords}

Intimate partner violence; family dispute resolution; religious values; belief; culture 


\section{Introduction}

Intimate partner violence (IPV) is an unfortunate reality of life for millions of women globally that jeopardize the well-functioning landscape of nearly all socioeconomic, religious, and cultural backgrounds (Kendall-Tackett, 2007; Ross, 2012). IPV includes acts of physical, sexual, and psychological coercion along with controlling behaviours by a current or former intimate $\operatorname{partner}^{1}$ (World Health Organization (WHO), 2013). Population-based studies report that $15-71 \%$ of women experience IPV worldwide (Garcia-Moreno, Jansen, Ellsberg, Heise, \& Watts, 2006). IPV has a devastating impact on women's lives; it affects women's physical, sexual, mental, and reproductive health (Garcia-Moreno, Jansen, Ellsberg, Heise, \& Watts, 2006; Islam, Baird, Mazerolle, \& Broidy, 2017; Islam, Broidy, Baird, \& Mazerolle, 2017a, 2017b; Trabold, Waldrop, Nochajski, \& Cerulli, 2013), and wellbeing (Krantz, 2002). More recently, due to these effects of IPV on women, views on IPV have started to shift from regarding it as a private or family matter towards a critical global health concern (WHO, 2013), a human rights issue (Amnesty International, 2004), and a challenge for social workers in terms of their practices (Goldblatt, Buchbinder, \& Eisikovits, 2009).

Not surprisingly, Muslims - a religiously and socio-culturally diverse faith-based populace - are not an exception regarding IPV. A recent systematic review on IPV among Muslims has reported that there is comparatively little information on the prevalence of IPV among Muslims around the world (Jayasundara, Nedegaard, Sharma, \& Flanagan, 2014). However, available studies report a high global prevalence of IPV among Muslims. A systematic review of studies from the Middle Eastern and North African Muslim countries

\footnotetext{
${ }^{1}$ Given the prohibition in Muslim religion of relationships outside of marriage (Al-Qaradawi, 1982), spouse or intimate partner in Muslim community refers to married partners only. This paper, therefore, focuses on violence against wife perpetrated by husband.
} 
documented that $8 \%$ to $65 \%$ of married women were physically assaulted by a partner during their marital life (Boy \& Kulczycki, 2008). Specifically, the prevalence of physical IPV is reported to be approximately $30 \%$ in Jordan (Haddad, Shotar, Younger, Alzyoud, \& Bouhaidar, 2011), 30-45.5\% in Saudi Arabia (Almosaed, 2004; Eldoseri \& Sharps, 2017), 55\% in Pakistan (Naeem, Irfan, Zaidi, Kingdon, \& Ayub, 2008), 28\% in Iran (Saffari et al., 2017), and 52.8\% in Bangladesh (Islam, Broidy, Baird, \& Mazerolle, 2017b). Many Muslim women also experience IPV in their countries of migration, such as the US, Canada or Australia (Ayyub, 2000; Faizi, 2001; Ghafournia, 2017; Hamid, 2015; Holtmann, 2016; Jayasundara, Nedegaard, Sharma, \& Flanagan, 2014). Although the prevalence of IPV varies from country to country, it is thus obvious that a significant number of Muslim women experience IPV.

Intimate partner violence in non-western culture is often viewed as a product of religion or tradition (Hunter, 2006). Religious beliefs play an important role in shaping the way people live, their social and cultural norms, and the attitudes and beliefs they exhibit towards IPV situations (Ibrahim \& Abdalla, 2010). When addressing IPV among Muslims whose lives are governed by Islamic faith; it is, therefore, crucial to take into account religious roles and beliefs (Jayasundara, Nedegaard, Sharma, \& Flanagan, 2014).

In non-Muslim context, some scholars advocate implementing a restorative justice (RJ) approach for the management of IPV cases because of its potential to handle IPV in a victim-sensitive way (Hayden, Gelsthorpe, Kingi, \& Morris, 2014; Presser \& Gaarder, 2000). Instead of simply punishing offenders, RJ aims to empower victims, their family, and communities by mending the harm caused by the crime (Wenzel, Okimoto, Feather, \& Platow, 2008). In this regard, RJ can also be a useful approach in addressing IPV in Muslim communities. This is because RJ approaches have been applied traditionally to resolve political, social, and ethnic conflicts (Hascall, 2012; Morris \& Trammell, 2011), and several studies have highlighted the compatibility of RJ approaches with Islamic teachings (Marder, 
2014; Qafisheh, 2012; Rahami, 2007). However, as is in the cases of RJ on IPV in nonMuslim context, there are potential challenges of implementing RJ on IPV in Muslim communities. Although implementation of RJ in dealing with IPV cases in some non-Western contexts, such as Gambia, South Africa or Thailand, has been to some extent examined (Dissel \& Ngubeni, 2003; Liebmann \& Wootton, 2010); to date, few studies have investigated the potential challenges of RJ in dealing with IPV cases in Muslim communities. Given the high prevalence of IPV coupled with various initiatives in addressing IPV among Muslims, the question is particularly important. Further, considering the growing number of Muslim immigrants across the world (Pew Research Center, 2011), and the fact that RJ practices are sometimes implemented by social workers (Beck, Kropf, \& Leonard, 2010), identifying challenges of implementing RJ on IPV among Muslims is timely, and can be useful for social work practice.

Accordingly, the aim of this paper is to discuss potential challenges of implementing RJ for the management of IPV cases in Muslim communities. First, in order to explore the standpoint of Islam to IPV, the paper discusses marital relationship and IPV from an Islamic perspective. Second, the relationship between RJ practices and IPV is briefly described. Third, the paper depicts RJ elements in Islamic approaches toward crimes and punishment. Fourth, the paper describes the Islamic solutions of IPV cases using RJ approaches, followed by examples of traditional RJ practices in different Muslim countries and communities. Fifth, drawing upon the extent Western and Islamic RJ literature on IPV, it discusses one significant challenge in implementing RJ in IPV situations among Muslims; that is, community acceptance of IPV. Finally, in relation to this problem, it concludes by providing policy recommendations to address the challenges of existing practices among Muslims in dealing with IPV situations. This paper will contribute to social work practice, education, and counselling because dealing with IPV through RJ in Muslim countries and communities 
requires social workers to be familiar with RJ practices as well as the intersection and difference of culture, religion, and spirituality.

\section{Marital relationship and Islamic Teaching}

As a religion, Islam is a complete and comprehensive guidance for mankind dealing with individual, familial, social, political, economic, ethical, national, and international aspects of life (Ammar, 2001). Qur'anic learning establishes that all human beings regardless of race, ethnicity, gender or class are equal in worth and value (Alwani, 2013). The Qur'an considers men and women to be partners, and makes it clear that no one has a level of moral authority over others. The most righteous between men and women is the most honoured in the sight of God (Qur'an, 9:71). There are many examples in the Qur'an and the Sunnah ${ }^{2}$ that depict the behaviour of married Muslim couples. The Qur'an describes the relationship between husband and wife as one of tranquillity, kindness, mutual love and affection, respect, caring, and mercy (Al-Hibri, 2003); as God says in the Qur'an, "O believers, treat women with kindness even if you dislike them; it is quite possible that you dislike something which God might yet make a source of abundant good" (Qur'an, 4: 19). The Qur'an repeatedly forbids a husband using injurious statements against his wife (Qur'an, 58: 2-4). The Prophet Muhammad (pbuh) said, "The perfect believer is one who is the best in courtesy and amiable manners, and the best among you people is one who is most kind and courteous to his wives" (Al-Tirmidhi, n.d, as cited in An-Nawawi, 1999, p. 271). Therefore, the Council of the

\footnotetext{
${ }^{2}$ The Sunnah is the sayings and example of Prophet Muhammad's (Peace be upon him, pbuh) life as narrated in the hadith (compilation of Sunnah). There are six major collections of ahadith (plural of hadith) named after the collectors, including Sahih Bukhari, Sahih Muslim, Sunan Abu Daud, Sunan al-Tirmidhi, Sunan al-Nasa'i, and Sunan Ibn Maja.
} 
International Islamic Fiqh Academy (IFA) ${ }^{3}$ declared all forms of family violence as a kind of injustice to women and is thus prohibited (Islamic Fiqh Academy (IFA), 2009).

Although a large number of Muslim men appear to engage in spousal violence disrespecting the religious teachings of love, sympathy, mercy, forgiveness, and harmony; IPV of any kind is contradictory to the principles of marriage in Islam (Al-Hibri, 2003; Ibrahim \& Abdalla, 2010). In various verses in the Qur'an, God warns that husbands who please their wives will earn God's pleasure, while husbands who treat their wives harshly will earn God's annoyance (Qur'an, 65:2, 4:19, 2:231, and 58:2-4). The Prophetic learning is that every husband should treat one's wife gently and patiently, and should not hurt her emotionally or physically in any way (Sunan Abu Dawud, n.d., 11: 2138-2139). In consideration of these relevant religious texts, it is clear that Islam does not endorse any type of violence or maltreatment against women.

A total of over 1.6 billion Muslims live in more than 184 countries, and they vary not only ethnically, but also linguistically and culturally (Ahmed, Amer, \& Killawi, 2017; Pew Research Center, 2011). Thus, a singular interpretation of religious texts is quite impossible while discussing Islam as an ideology (Ammar, 2007). In spite of the existing diversity among Muslims, most acknowledge that the Holy Qur'an, and the hadith and sunnah are the major sources of Islamic guidelines. In spite of the condemnation of any kind of violence against women, spousal violence happens because of misogynistic misinterpretations, misunderstandings of Islamic law by the perpetrators, and cultural and patriarchal interpretations of these religious texts (Al-Hibri, 2003; Faizi, 2001; Ibrahim \& Abdalla, 2010). Perpetrators generally use some particular Qur'anic texts to create a religious 'alibi' in

\footnotetext{
${ }^{3}$ The IFA is an institute for the advanced study of Islam based in Jeddah, Saudi Arabia which generally promotes the interpretational reflection of Islamic jurisprudence or fiqh. It was established by the Organization of the Islamic Conference (OIC) in 1981. It is comprised of 43 Islamic jurists from their respective nations.
} 
order to justify spousal violence (Douki, Nacef, Belhadj, Bouasker, \& Ghachem, 2003). However, some of the common factors associated with experiencing IPV among Muslim women include rural residence, lower level of education, lower household income, nonworking status, lower decision-making autonomy, husband's controlling behaviours, husband's substance abuse, endorsement of traditional gender roles, and justification or acceptance of wife beating among men and women (Al-Nsour, Khawaja, \& Al-Kayyali, 2009; Boy \& Kulczycki, 2008; Islam, Mazerolle, Broidy, \& Baird, 2017; Jayasundara, Nedegaard, Sharma, \& Flanagan, 2014; Saffari et al., 2017). In addition, a range of psycho-socio-cultural factors, including varied religious and cultural traditions, are known to complicate the contextual circumstances of IPV (Boy \& Kulczycki, 2008; Islam, Mazerolle, Broidy, \& Baird, 2017; Islam et al., 2017; Jayasundara, Nedegaard, Sharma, \& Flanagan, 2014).

There is a complex association between culture and religion, because of the overlapping nature of religious beliefs and cultural values (Ghafournia, 2017). As culture is sometimes influenced by religion; in reality, it is quite hard to separate culture from religion (Ghafournia, 2017; Hassouneh-Phillips, 2001). Culturally, Muslims place a high value on the marital relationship, abstaining from divorce, and keeping family matters private. Similar to other non-Muslim societies, Muslims also view IPV as a private, personal, and family issue instead of a social and criminal justice problem that requires social welfare and social control agents (Haj-Yahia, 1998). This attitude has developed from the socio-cultural context of Muslim families, where the emphasis is given on the privacy, solidarity, and reputation of the family (Douki, Nacef, Belhadj, Bouasker, \& Ghachem, 2003). Moreover, the majority of Muslim men think that a wife is accountable to her husband for her behaviour and daily activities, and that violence is acceptable as a corrective punishment (Douki, Nacef, Belhadj, Bouasker, \& Ghachem, 2003; Hadi, 2005; UNFPA, 2003). Like other non-Muslim societies, traditional societal norms, such as male dominance, and female subjugation and subordination become internalized and integrated into the Muslim culture so much so that women 
themselves support a man's right to beat his wife under certain circumstances (GarciaMoreno, Jansen, Ellsberg, Heise, \& Watts, 2006; Haj-Yahia, 2010; Jewkes, 2002; Uthman, Moradi, \& Lawoko, 2009). These circumstances include, for example, if a woman does not obey her elders, goes out without telling her partner, neglects their children, argues with him, refuses to have sex with him, or does not cook the family food to the standard deemed acceptable by the partner (Boy \& Kulczycki, 2008; Garcia-Moreno, Jansen, Ellsberg, Heise, \& Watts, 2006). Unfortunately, some perpetrators apply religious rules and values to support and justify violent behaviours that are actually based on traditional cultural beliefs such as patriarchy and assumptions of male dominance and women subordination (Ghafournia, 2017). Therefore, social workers need to consider the intersection and difference of culture and religion, because people commonly misunderstand several cultural practices as religious customs, such as dowry, female genital mutilation, and honour killing.

\section{Restorative Justice Practices and Intimate Partner Violence}

No consensus has been made to date on the definition for RJ (Daly, 2016; Wood \& Suzuki, 2016). However, a process that involves a face-to-face dialogue between stakeholders is basically regarded as an RJ approach (Daly, 2016). In general, RJ consists of two stages: story-telling and outcome discussion. In the story-telling phase, participants have the opportunity to discuss "what happened and how the crime impacted on them". This is followed by the outcome discussion phase that involves a discussion on "what should be done to mend the harm caused by the offence" (Daly \& Hayes, 2001). RJ specifically focuses on 'restoration, healing, reconciliation, reintegration, participation — when appropriate forgiveness' (Pavlich, 2005, p.2). The RJ approaches may include victim-offender mediations, family group conferences, community mediation, sentencing circles, reconciliation commissions, and informal tribunals (Castella, Platow, Wenzel, Okimoto, \& 
Feather, 2011). The first two approaches are the most widely used RJ practices in the context of IPV (Drost et al., 2015).

Although the feminist antiviolence activism and the RJ movement have evolved from different perspectives including social work (Umbreit, 1993), both of them are largely concerned with the effect of crime on victims and the society, and both make a range of identical critiques of the existing criminal justice system, such as it being mostly offenderoriented and neglect the needs of IPV victims (Hopkins, Koss, \& Bachar, 2004; Ptacek \& Loretta, 2009). Unlike the conventional criminal justice processes, RJ approaches are victimfocused in the sense that they can incorporate victims' experiences as survivors of IPV (Hopkins, Koss, \& Bachar, 2004), and they aim to hold perpetrators of IPV accountable for their abusive behaviours (Drost et al., 2015). In addition, victims can be actively engaged in the decision-making process in dealing with their abusers, and receiving support from the communities to help stop violence (Morris, 2002; Presser \& Gaarder, 2000).

In spite of these benefits, suitability of RJ for IPV cases has remained largely unexplored in non-Western context, particularly in Muslim countries. However, the appropriateness of RJ practices for IPV situations remains a debated issue even in Western RJ literature (Daly, 2012; Daly \& Stubbs, 2006; Mills, Maley, \& Shy, 2009; Stubbs, 2004) because of concerns that these practices may actually re-victimise victims of IPV due to power imbalance between victims and perpetrators (Goel, 2005; Hovell, Seid, \& Liles, 2006). This may also be partly because there exists few empirical research of RJ on IPV cases, and while some research showed that RJ generated victim satisfaction (Dissel \& Ngubeni, 2003; Kingi, Paulin, \& Porima, 2008; Tisdall, Farmer, Robinson, Wells, \& McMaster, 2007), the limited extant studies arguably show negative outcomes in terms of victim attitudes toward offenders and recidivism (Bahinger \& Pelikan, 2015; Pelikan, 2010).

\section{Restorative Justice from an Islamic Perspective}


One of the primary roots of $\mathrm{RJ}$ is in religions, traditions, and customs of problemsolving; therefore, the applicability of RJ to communities and societies that have socioeconomically, religiously and culturally different backgrounds have been discussed elsewhere (Hadley, 2006, 2001; Mburia-Mwalili, Clements-Nolle, Lee, Shadley, \& Yang, 2010). Restoration, healing, reconciliation, reintegration, participation, and forgiveness are some important elements of the RJ process (Pavlich, 2005). These elements are entirely consistent with teachings of Islam. From a holistic perspective, the Qur'an is a message of love, mercy and forgiveness. It would be worthwhile to mention some of the relevant Qur'anic verses highlighting forgiveness and mercy. God forgives anything except worshiping others with Him (Qur'an, 4:48). God assures that if anyone does bad deeds, but afterward seeks God's forgiveness, God will forgive him or her (Qur'an, 5:110). Emphasizing forgiveness and reconciliation, God says the compensation for an injury is an equal injury, but if one forgives and makes reconciliation, he will be rewarded from God (Qur'an, 25:40); and forgiveness and reconciliation supersedes injury for injury (Qur'an, 42:40).

Mediation (Wasaata), arbitration (Tahkim) and reconciliation (Sulh) are three terms found in Islamic law that refer to the friendly dispute resolution between parties that makes relationships peaceful (Malik, 2014). Traditionally, Arab countries have used these settlement practices to resolve individual, familial and group conflicts (Al-Krenawi \& Graham, 2001; Hascall, 2012; Morris \& Trammell, 2011). To understand the Islamic perspective of RJ, it is necessary to understand that different procedures and punishments are applied to different types of crimes in accordance with the Qur'an, as we see next.

According to Islamic criminal jurisprudence, crime can be divided into three categories: hudud, qisas, and tazeer crimes (Ammar, 2001; Okon, 2014). Hudud crimes are considered to be the most serious in nature, and the penalties for those crimes are mandated either in the Qur'an or in the Sunnah, and the punishment cannot be altered (Ammar, 2001). Their punishment is the harshest, because the perpetrator violates the right of God by 
impairing the harmony of the community created by God (Ammar, 2001). Hudud crimes include fornication or adultery, false accusation of adultery, drinking alcohol, highway robbery, theft, rebellion against the state and apostasy (Haqqi, 2015; Okon, 2014).

Qisas (retaliation) crimes include all types of murder and crimes against persons that cause bodily harm or death (Ammar, 2001). The punishments for qisas are not proclaimed in the Qur'an; however, retaliation, compensation, and reconciliation are prescribed (Ammar, 2001; Haqqi, 2015; Rahami, 2007). In dealing with qisas crimes, the victim's roles and demands become vital in converting the penalty from retributive to restorative because forgiveness that can lead to compensation (diyya); and reconciliation (sulh) can only be initiated with the consent of the victim (Ammar, 2001; Hascall, 2012; Rahami, 2007). For example, if someone is murdered, the family of the victim could demand the perpetrator's death sentence, or they could pardon the criminal, and demand blood money instead (diyya). Thus, qisas crimes and punishment have some commonalities with RJ (Hascall, 2012).

Tazeer (chastisement) crimes include all crimes which affect the right of the community and for which the Qur'an or the Sunnah do not prescribe any punishment, (Ammar, 2001; Haqqi, 2015). The tazeer crimes are embezzlement, perjury, usury, breach of trust, abuse, bribery (Hascall, 2012), and cheating in the marketplace (Haqqi, 2015). The punishment for Tazeer crimes depend on the discretionary power of the judge and may range from a warning to death (Haqqi, 2015). But, tazeer crimes also have the potential to convert retributive to restorative justice. Ammar (2001) has prescribed that the practice of RJ, such as mediation, victim-offender conferences, and victim's compensation programs, can be implemented in tazeer crimes.

From the aforementioned classification of crimes in Islamic law, it is apparent that both qisas and tazeer crimes and punishments have some elements that are very consistent with that of RJ. These types of punishments have the potential to be transformed from retributive to restorative justice on the ground of some commonalities with elements of RJ: 
compensation, conciliation, and forgiveness. Hence, one recent study concludes that Islamic jurisprudence of criminal law resembles the modern RJ practices (Qafisheh, 2012).

\section{The Islamic Restorative Justice Solution to Intimate Partner Violence}

Based on the gravity of crimes, there is a clear distinction between public and private aspects of crime. Hudud crimes, by their extent and nature, are characterized as public crimes,

where as qisas and tazeer crimes have private aspects of offence. Conciliation is possible if the crime is regarded as a private matter, as it is provisional to the approval of the victim (Qafisheh, 2012; Rahami, 2007). Amongst three categories of crimes in Islamic criminal law, IPV belongs to the category of qisas crimes because crimes against individuals by assault, battery, or mayhem that cause bodily harm or death are termed as qisas crimes (Ammar, 2001). For instance, in Pakistan, an Islamic State as per its Constitution, most acts of IPV are encompassed by the qisas and diyya Ordinance (Human Rights Watch, 1999). If an IPV case comes before a criminal court, it is generally prosecuted either by qisas or diyya for the benefit of the victimized woman or her relatives (Human Rights Watch, 1999).

In the Qur'an, specific measures are prescribed to settle IPV cases. A peaceful discussion between the husband and the wife about the problem is recommended first for obtaining an amicable solution (Qur'an, 4:34). If they fail to resolve their differences with mutual discussion, the Qur'an then recommends an arbitration system in verse 4:35 to resolve interpersonal disputes on the condition that both the husband and the wife must have the desire for reconciliation. The Qur'an strongly advocates amicable settlement of disputes on fair and equitable grounds, and God gives divine blessings to those who reconcile. In the Qur'an, God advises the following procedure for reconciliation between married couples in the context of marital conflicts: 
And if you fear a breach between the two, then appoint one arbitrator from his family and one from hers; if the couple wishes to reconcile, God will cause their reconciliation: surely God is All-knowing, All-aware. (Qur'an, 4:35)

If this reconciliation process, with the help of arbitrators from both sides, is not able to reach an agreement in any way, then the couple may seek a divorce. In this regard, God warns men that they should not use divorce as a tool to do harm to their wives in any way:

Retain them in kindness or release them in kindness. But do not retain them to their hurt so that you transgress (the limits). If anyone does that he wrongs his own soul. Do not take God's instructions as a jest. (Qur'an, 65:2)

Muslim countries, practicing Islamic Law, thus arguably adopt RJ approaches in mediating IPV situations. In its process, an impartial mediator assists disputant parties in finding a mutually acceptable solution. Islamic mediation is based on equal representation from each side, collaborative problem solving, a win-win solution between parties, and respect for all concerned.

\section{Examples of Islamic Restorative Justice Approaches towards Intimate Partner Violence}

To our knowledge, only a few studies show examples from Muslim countries and communities that are practicing RJ in mediating IPV in accordance with Islamic teachings. Here, three examples are presented from Northern Nigeria, Malaysia, and Bangladesh. Northern Nigerian Muslims practice the customary Islamic arbitration in the form of Tahkim (arbitration) and Sulh (reconciliation) as prescribed in the Islamic (Shari'ah) law (Malik, 2014). They practice one kind of matrimonial dispute settlement process through reconciliation, with the mediating role of the Imam, a leader of a mosque. In this process, someone from the family informs the community Imam about the problem. The Imam then invites the couple to meet with him in the mosque and inform him about the causes of conflict between the couple. After hearing them, the Imam makes a critical judgement of the case, and 
asks for two people from the family who are aware of the dispute, and who are also respected in the family, to reconcile the husband and the wife. The Imam, as well as the two mediators, advise the couple about the consequences of enmity on their children and family, and encourage them toward a peaceful dispute settlement. In this way, the mosque and the Imam, as an institution, play a vital role in the reconciliation process of a marital conflict resolution in Nigeria (Malik, 2014).

For the reconciliation of marital disputes in Malaysia, mediation has formally been used in the Shari'ah courts, and informally by religious personnel and community-based mediators (Bagshaw, 2008). Bagshaw (2008) reported two processes of mediation in family dispute resolution that are practiced by the Malay Muslim society. First, informal mediation can be facilitated by family members, neighbours, the village headman (penghulu) and the Imam informally. In every village, traditional mediators and untrained counsellors, as well as mediators in the religious office, usually play an important role in resolving family disputes. When assisting the Muslim couple in reaching consensus, the mediator usually emphasises the Qur'anic teachings regarding their parental and spousal responsibilities, and focuses on keeping the family bonding intact. If the couple fails to reconcile even with the help of mediators, the case is referred to the Shari'ah court, where a judge handles the case. Second, formal mediation by the Shari'ah courts takes place. Cases are referred to the court when disputes are complicated and informal mediators are unable to reconcile the couple. In this case, the court applies the following mediation process: (a) Mediation by arbitrators and the conciliatory committee to reconcile the parties in dispute; and (b) Mediation to reach an amicable solution in divorce-related issues. At all levels, the mediation focuses on reconciliation (Bagshaw, 2008).

Intimate partner violence in Bangladesh has generally been resolved either among relatives or in village shalish (Ashrafun \& Säävälä, 2014). Shalish is a village-based traditional mediation conference that helps to resolve community members' disputes (Golub, 
2003). Shalish is administered and facilitated by three different entities. First, traditional shalish is administered by shalishkars (arbitrators), usually comprising local leaders, local elites, local public representatives, religious leaders, and the elderly. In the traditional shalish process, shalishkars may be involved in arbitration, mediation or a combination of the two. Second, "village court" - an alternative dispute resolution system to deal civil disputes (family matter, land dispute, property crime, marriage and divorce etc.) and minor criminal offences (theft, rape, cheating, coalition, mischief etc.) - is held. The Muslim family laws ordinance of 1961 empowers the Union Parishad (UP, the lowest body of local government) to reconcile family disputes. The Village court ordinance of 1976, and the conciliation of dispute ordinance of 1979 provides power to village courts to settle some civil and criminal cases. The UP chairman and members play a vital role in the arbitration process in village courts. Third, NGOs facilitate shalish, where NGOs play an important role in initiating and facilitating shalish. NGOs usually try to preserve the rights of women in the shalish process and provide legal and mental support to abused women in the rural areas (Golub, 2003).

\section{Challenges in Implementing RJ Approaches to IPV in Muslim Communities}

There is controversy over the application of RJ on IPV because IPV is different from other types of crime in some aspects, such as an ongoing relationship between victims and offenders, and inequality between victims and offenders established by (persistent) violence (Drost et al., 2015; Tisdall, Farmer, Robinson, Wells, \& McMaster, 2007). Every RJ approach in Muslim countries and communities has been established to benefit the stakeholders. However, misapplication of these approaches can cause some harm instead of good. Since the appropriateness of RJ approaches to IPV in the Western contexts has been discussed elsewhere (Daly, 2012; Daly \& Stubbs, 2006; Mills, Maley, \& Shy, 2009; Morris \& Gelsthorpe, 2003), examining available literature, this section discusses one significant 
challenge in the RJ approaches used to mediate IPV cases in Muslim countries and communities: community acceptance of IPV.

Some feminist scholars have opposed using RJ approaches to IPV, because it may lead to denying the public aspects of IPV that require state involvement- - because of its severityby turning IPV cases into private matters to be resolved between victims and offenders (House \& Hargovan, 2011; Kohn, 2010). Restorative justice advocates claim that involving community members in the process can prevent IPV as they can support victims during the process, and oppose men's violence (Morris, 2002). However, the effect of community involvement and support is doubtful because communities tend to be patriarchal (Cunneen, 2003), and may have a norm that (implicitly) accepts IPV (Drost et al., 2015; Frederick \& Lizdas, 2009; Stubbs, 2007). In fact, it is a concern of IPV victimized women whether the community is able to show appropriate attitudes or levels of understanding towards IPV to help them (Rubin, 2009).

Such a norm towards IPV in the society raises a question about the effectiveness of the RJ approach in changing IPV offenders' attitudes and behaviours. The reintegrative shaming theory proposed by John Braithwaite (1989) is considered one of the main theoretical foundations of RJ approaches. It posits that reintegrative shaming, which shows disapproval of offenders' acts while accepting offenders themselves, is more effective to change offenders than stigmatising shaming, which expresses disapproval of offenders, labelling them as deviant. Research demonstrates that RJ approaches create a more reintegrative environment than traditional court processes (Harris, 2006), and another study shows the potential of the shaming strategy in dealing with offenders of IPV (Loeffler, Prelog, Unnithan, \& Pogrebin, 2010). But the problem is that the shaming strategy requires a universally accepted view that offences are not acceptable (Braithwaite, 1989), and that in the RJ process offenders' violence toward their partners needs to be condemned by the participants, including community members (Presser \& Gaarder, 2000). As mentioned, there may not be such an agreed view 
towards IPV in some communities and societies (Busch, 2002). Further, in the "informal" RJ process, the message that violence towards their partners is unacceptable is not as clear as the formal retributive process, because dialogue between victims and offenders may create a message that both have responsibility for IPV (Frederick \& Lizdas, 2009). Therefore, some critics suggest that it is naïve to believe that RJ approaches, which posits that both parties are equal, can change offenders' attitudes and behaviours without addressing the prevailing societal norms against IPV (Cheon \& Regehr, 2006; Kohn, 2010).

This challenge is apparently persistent in the facilitators' characteristics in the current RJ practices in Muslim countries/communities. Either in the Islamic Arbitration by Imams in Northern Nigeria, or in the shalish process in Bangladesh, the head along with other panel members are predominantly males who often lack a full understanding of the family dynamics of experiencing IPV. Some shortcomings of the Islamic Arbitration are reported as follows: 1) women were sometimes blamed by the Imams for the marital conflict, and accused of not pleasing their husbands; 2) the Imams occasionally wrongly advised the women to place the importance of family privacy above any harm that they might endure; 3) sometimes the individuals sitting on the arbitration panels were individuals who have a close personal relationship with the husbands involved in the dispute, and their objectivity might be questionable as well (Faizi, 2001; Ghafournia, 2017). The absence of a neutral arbiter or mediator in the traditional shalish panel was also found in Bangladesh (Ashrafun \& Säävälä, 2014). These studies suggested that aforementioned challenges arose due to the strong patriarchal norms, and attitude toward holding women responsible for IPV. Moreover, drawing upon interviews with 20 IPV victims and six lawyers, and observing 10 mediations in a counselling centre in Bangladesh, Ashrafun and Saavala (2014) also found that traditional shalish panels consisted of exclusively male members, some of whom unlawfully influenced the mediation process as influential local figures, favoured men over women, and disallowed the presence of victim women in the shalish process. Due to these drawbacks in the shalish 
process, Ashrafun and Säävälä (2014) concluded that the abused women were unable to obtain a just outcome in some cases.

The available literature, therefore, indicates that Muslim RJ approaches to address IPV cases have common challenges observed in the Western countries. Though Islamic mediation is based on equal representation from each side, the available literature shows that abused women were sometimes not allowed to remain present like for the shalish process (Ashrafun \& Säävälä, 2014). In the Islamic mediation process, an impartial mediator is supposed to help disputant individuals in finding a mutually acceptable win-win solution. Nevertheless, Ashrafun and Säävälä, (2014) pointed out that impartiality and neutrality of shaliskers are found to be compromised during the shalish process. Additionally, panel members sometimes hold women responsible for the unwanted situations, and they in turn unjustifiably advised victims of IPV to make an effort to please their husbands. As a result, due to the facilitator's biased role, the mediation process fails to ensure equity and equality in the legal and social justice of IPV victims.

\section{Policy Recommendations}

Existing criminal justice systems are not without criticisms in their dealings with IPV cases (Hayden, Gelsthorpe, Kingi, \& Morris, 2014; Hopkins, Koss, \& Bachar, 2004). In some developing countries, particularly in South Asia, the legal system is potentially corrupt, inefficient, unpredictable, often expensive, and takes years to reach a verdict (Maranlou, 2015; Moran, 2015). Therefore, the economically disadvantaged Muslim victims of IPV strongly prefer RJ practices over divorce or legal proceedings as a justified method for resolving marital disputes (Ashrafun \& Säävälä, 2014). Due to limitations of the traditional criminal justice systems; activists, practitioners, and scholars are increasingly trying to find alternative measures to deal with IPV cases successfully and justifiably both at societal and state level (Douglas, 2008; Erez, 2002). 
When implementing RJ in IPV cases, it is very crucial to make a distinction between situational couple violence and coercive control in intimate relationships also known as intimate terrorism. In contrast to situational couple violence, coercive control is connected with recurrent, escalating violent acts along with the exercise of power and control that puts victim women socially isolated and in extreme fear (Johnson, 2006). Because of the complexity of IPV, the implementation of RJ in IPV cases is particularly challenging not only in Europe, but also in North America, Australia, New Zealand, and other corners of the world (Drost et al., 2015). Victim-offender mediation can be disastrous in case of coercive control; while in case of situational violence, the application of mediation may be useful and effective, in particular when children are involved, to decide, for instance, agreements on safe and caring visiting (Pelikan, 2010). Moreover, RJ practice might be particularly effective when applied with 'first-time' offenders, and when the offence is associated with alcohol or drug abuse (Dissel \& Ngubeni, 2003). As a result, a single criminal justice approach will unlikely be suitable for dealing with all IPV cases, and flexibility with managing victims, various types of offenders, and types of relationship is very crucial. For this reason, identifying those cases for which RJ approaches have great potential is necessary. In spite of reservations, many scholars are of the opinion that RJ approaches do have potential in dealing with some particular IPV cases (Castella, Platow, Wenzel, Okimoto, \& Feather, 2011; McCold, 2003). Almeida and Lockard conclude, 'this system of intervention offers a range of new options: the possibility of victims returning to their now non-violent partners, the possibility of children rebuilding relationships with their abusive parent, the possibility of having a civil and safe divorce, and last, the possibility of maintaining safety through community rather than criminal justice intervention' (Almeida \& Lockard, 2005, p.25). However, it is unsettled whether RJ is the best criminal justice method in practice when dealing with perpetrators of IPV, particularly as formal retributive justice may provide greater protection to victims and their families (Coker, 2002; Stubbs, 2002). 
Ammar (2001) argues that advocating RJ in Muslim communities is not a difficult task because RJ ideas in Islam have a theoretical and practical foundation in conflict resolution. Given the aforementioned potential challenges facing Muslim communities, however, meaningful measures are warranted to address the existing issues in Islamic RJ practices for the management of IPV cases. To overcome the reservations found in the Western contexts, Stubbs (2007) for example suggests that IPV cases may require a hybrid model of RJ that would consist of both formal criminal justice and restorative justice methods because the RJ process should have the backup force of the legal system as a last resort (Braithwaite \& Strang, 2002). Miller and Iovanni (2013), on the other hand, suggest that the RJ process should be held after sentencing so that it can resolve the problem of norms against IPV, because perpetrators are already denounced in the sentencing process.

Since the above are proposed in the Western context, in consideration of our identified challenges, we provide a more specific prescription compatible with the Islamic perspective. As discussed above, bias among male facilitators is one of the most important challenges pertaining to Muslim RJ practices in handling IPV situations, Ammar (2001) suggests representation of women facilitators in the RJ process, particularly with women as judges or arbitrators, because facilitators of the RJ process should understand the power dynamics of IPV (Kohn, 2010). Moreover, in the Islamic arbitration panel and shalish panel, equal representation of male and female members need to be incorporated in order to neutralize male dominance in the arbitration and mediation process. Female panel members can resolve the complex situations of IPV having a private discussion with the abused woman, and can play an important role in the marital conflict resolution by upholding the rights of the women. Local NGOs and other women's organizations also need to be involved in the mediation process to act as both a watchdog and a pressure group towards the offender, to avert the contravention of agreements. 
That said, such a significant change may be difficult and may take a long time. We, therefore, provide more immediate strategies to implement. As IPV is not a homogeneous phenomenon, rather one that consists of a wide range of offences (Hovell, Seid, \& Liles, 2006), Muslim male mediators and social workers must be sensible of the risk factors contributing to conflict among Muslim couples. They should undergo training about the dynamics of IPV that debunks the existing myths about IPV, understand the reasons why Muslim victims choose to remain in relationships, validate the experiences of Muslim IPV victims, and hold the offender responsible for his abusive behaviours for socially just outcomes. Therefore, effective education and training in social work, human psychology, family relations, and family dynamics have to be offered to the mediators and social workers in order for them to firmly grasp the complex issue of IPV (Burkemper \& Balsam, 2007; Drost et al., 2015). Practitioners should assist married couples in addressing, preventing, and reconciling IPV situations by facilitating the teachings of polite treatment and care of wives mentioned in Islamic religious texts. Muslim male arbitrators and mediators need to perform their social responsibility in the RJ process in an unbiased and fair manner as dictated by the religious texts and state laws. As a male facilitator, it is also an offence in the eyes of Islam to unjustly favour a male over female. To check their appropriateness as a facilitator in practice, mediators involved with IPV cases need to be monitored regularly by the state in order to ensure how effectively and efficiently they respond to the complex nature of this social challenge of safeguarding the safety, justice, equity, equality, and rights of the victimised women. In addition, family dispute resolution practitioners and community leaders need to work together in the community for an effective resolution of IPV within cultural customs, religious principles, and teachings. Well-trained lawyers, social workers, religious scholars, and psychologists need to work as a team of family mediators to deal with IPV cases successfully utilising their respective expertise for a mutually beneficial outcome. 
The victims' voices are critical in RJ implemented practices for mutually beneficial outcomes. The fear of being killed by a violently abusive partner is the reason for victimised wives to want to leave an abusive relationship (Davies, 2009). This may also be the case when they feel it difficult to ensure their children's physical and emotional safety. Children exposed to parental violence may experience violence as direct victims, bystanders or as witnesses used as weapons, forced to watch or participate, be blamed, and required to intervene to stop the violence. Not only do children exposed to parental violence experience immediate distress and uncertainty, but they also are likely to face difficulty in adjusting (Davies, 2009). Children who are exposed to IPV have been reported to have high rates and increased risk of: intentional self-harm and suicide, experiencing emotional, physical and sexual abuse, lower levels of self-esteem, and below average academic performance, entering into the foster care system, and being exposed to the juvenile justice system (Australian Human Rights Commission, 2015). Witnessing and experiencing childhood abuse in domestic violence homes has been shown to influence later adult relationships of IPV perpetration and victimisation through the socialisation process (Adam \& Schewe, 2007; Eriksson \& Mazerolle, 2015; Flood \& Pease, 2009; Islam et al., 2017). When children observe parents persistently resorting to violence to resolve conflict, they learn more functionally positive outcomes to violent behaviour than negative consequences of it. They do not learn skills like negotiation, verbal reasoning, self-calming tactics, and active listening to resolve the conflict. Witnessing violence among parents in childhood conveys powerful messages about culturally sanctioned male-female roles and behaviours. The RJ process has to take into consideration the long-term negative consequences of prolonged exposure to violence that IPV has not only on victims but also on their children exposed to the violence.

Proper safety planning, and psychological, sociological, and therapeutic interventions are required for the victimised women who decide to leave violent relationships with their children. In line with RJ processes healing of victims is an essential process where their 
experiences are validated and their recovery facilitated. Neither can victims nor their children who have experienced or witnessed abuse move forward unless their emotional, social and economic needs are addressed to restore their human dignity.

Through this process of inclusion of the victims' voices, family, and community takes responsibility for the safety of victims and holding offenders accountable to combat violence, and speak out against abusive relationships. Cultural and religious-sensitivity are paramount in the adaption, as transferring retributive strategies of addressing IPV risks being discredited as incompatible with Muslim religious and cultural beliefs. Social workers in dealing with IPV situations can adapt their responses to meet societal conditions of Muslims that capitalise on the strength of the community to prevent IPV. Restorative justice involves a discussion on what the perpetrator can do for the harm that he has caused in his relationship with his wife, and be held accountable for actively participating in the healing process.

\section{Implications for Social Work}

Although the concept of RJ has gained much attention in the criminal justice arena, it has been largely overlooked in the field of social work (Van Wormer, 2003, 2006; Wong \& Wing Lo, 2011). Synthesizing 80 social work articles dealing with RJ, A recent systematic review concluded that the responsibilities of social workers as authors, researchers, and participants in RJ programs and practices remain significantly fairly unknown, and suggested for augmenting social work practice in RJ area (Gumz \& Grant, 2009). With the core value of working with the vulnerable and suppressed populations for social justice, social workers have an excellent opportunity to be actively involved in RJ programs so that justice can be ensured for victims, offenders, communities, and their families. In spite of some commonalities between the values and goals of RJ professionals and social workers, it is widely criticized that social workers are lacking the proper knowledge and advanced training in successfully handling RJ cases not only in RJ pioneering countries but also in countries where RJ practice is currently in infancy (Baldry, 1998; Van Wormer, 2006). Therefore, 
social workers' participation, training, and education in RJ programs and practices are highly warranted. The theory, principles, and practices of RJ (particularly family mediation) need to be included in the social work curriculum. More specific education and training in family relations, and family dynamics of Muslims have to be included in the curriculum in order for the social workers to clearly understand the complex issue of IPV among Muslim couples. Since the core values of RJ practice have spiritual and/or religious roots (Gumz \& Grant, 2009), and religion and spirituality play a key role in the lives of many Muslims, social workers can utilize religious rituals and concepts that are culturally specific to the participants when dealing with RJ cases. To this end, social workers need to be familiar with the intersection and difference of culture, religion, and spirituality when handling RJ cases among Muslim immigrants in Western countries; because most often, it is difficult for a social worker in Western settings to differentiate what is cultural practice and what is religious rituals. Until recently, RJ approaches are being practiced mostly in the rural areas of Muslim countries upholding their traditional cultural practices; whereas, urban populations are not much inclined to RJ approaches as their attitudes towards traditional cultural practices have been gradually changed due to urbanization, higher education, and changing roles of women in the family. Thus, in order to deal with RJ cases in countries with large Muslim populations, careful attention needs to be given in engaging professional social workers equipped with culturally specific training and education, if they are not already in place. Social workers' active participation in dealing with RJ will minimize the gaps in the existing literature on social work practice, education, and research with Muslim population in the coming days (Husain, 2017).

\section{Conclusion}

Muslim women sometimes endure harsh treatment from their husbands due to ignorance of their Islamic rights, and often they do not realise that their husbands are 
exceeding limits prescribed by Islam (Faizi, 2001; Ibrahim \& Abdalla, 2010). Abusive Muslim men are neglecting not only the Islamic teachings of kindness, mercy, politeness, and forgiveness, but also the examples of the Prophet Muhammad (pbuh), who always condemned any kind of violence against women. Muslims have a social responsibility mandated in the religious texts to speak out against any kind of oppression and injustice. Muslim countries and communities should practice the marriage-related teachings of the Qur'an, and the hadith, which strongly emphasises that the rights and entitlements of all people ought to be maintained in order to ensure justice and peace in the society. To reduce IPV in Muslim society, it is necessary to develop treatment models and techniques that address cultural and religious needs. Since RJ is not alien to Islamic teachings, RJ approaches can be implemented in some cases of IPV among Muslims in a victim-sensitive way by ensuring safety, justice, equity, and the rights of the abused woman as prescribed in the religious texts.

\section{References}

Adam, N. M., \& Schewe, P. A. (2007). A multilevel framework exploring domestic violence against immigrant Indian and Pakistani women in the United States. Journal of Muslim mental health, 2(1), 5-20.

Ahmed, S. R., Amer, M. M., \& Killawi, A. (2017). The ecosystems perspective in social work: Implications for culturally competent practice with American Muslims. Journal of Religion \& Spirituality in Social Work: Social Thought, 36(1-2), 48-72.

Al-Hibri, A. Y. (2003). An Islamic perspective on domestic violence. Fordham International Law Journal, 27(1), 195-224. doi: 10.1080/15265160701220907

Al-Krenawi, A., \& Graham, J. R. (2001). The cultural mediator: Bridging the gap between a non-Western community and professional social work practice. British Journal of Social Work, 31(5), 665-685. doi: 10.1093/bjsw/31.5.665 
Al-Nsour, M., Khawaja, M., \& Al-Kayyali, G. (2009). Domestic violence against women in Jordan: evidence from health clinics. Journal of family violence, 24(8), 569-575.

Al-Qaradawi, Y. (1982). The lawful and the prohibited in Islam. Indianapolis, IN: American Trust Publications, USA.

Almeida, R., \& Lockard, J. (2005). The cultural context model. In N. J. Sokoloff \& C. Pratt (Eds.), Domestic violence at the margins: Readings in race, class, gender and culture (pp. 319-332). Piscataway, NJ: Rutgers University Press.

Almosaed, N. (2004). Violence against women: A cross-cultural perspective. Journal of Muslim Minority Affairs, 24, 67-88.

Alwani, Z. (2013). Domestic violence: Islamic perspective. Retrieved 30 August, 2015, from http://www.zainabalwani.com/domestic-violence-islamic-perspective/

Ammar, N. H. (2001). Restorative Justice in Islam: Theory and Practice. In M. L. Hadley (Ed.), The Spiritual Roots of Restorative Justice (pp. 161-180). Albany, NY: State University of New York.

Ammar, N. H. (2007). Wife Battery in Islam: A Comprehensive Understanding of Interpretations. Violence Against Women, 13(5), 516-526.

Amnesty International. (2004). Making violence against women count: Facts and Figures - a summary. ACT 77/034/2004 (Public). Retrieved 8 December, 2014

An-Nawawi, A. Y. (1999). Riyad-Us-Saliheen. Riyadh, Saudi Arabia: Maktaba Dar-us-salam. Ashrafun, L., \& Säävälä, M. (2014). Domestic violence made public: A case study of the use of alternative dispute resolution among underprivileged women in Bangladesh. Contemporary South Asia, 22(2), 189-202.

Australian Human Rights Commission. (2015). The children's rights report 2015. from https://www.humanrights.gov.au/sites/default/files/AHRC_ChildrensRights_Report_2 $\underline{0150 . p d f}$ 
Ayyub, R. (2000). Domestic violence in the South Asian Muslim immigrant population in the US. Journal of Social Distress and the Homeless, 9(3), 237-248.

Bagshaw, D. (2008). Family violence and mediation: Does culture make a difference? Retrieved from http://www.asiapacificmediationforum.org/resources/2008/22Dale_Bagshaw.pdf

Bahinger, L. M., \& Pelikan, C. (2015). Victims' experiences in victim-offender mediation in Austria: The 'real' story. In I. Vanfraechen, D. Bolivar \& I. Aertsen (Eds.), Victims and Restorative Justice (pp. 83-106). Oxon, UK: Routledge.

Baldry, A. C. (1998). Victim-Offender Mediation in the Italian juvenile justice system: The role of the social worker. The British Journal of Social Work, 28(5), 729-744.

Beck, E., Kropf, N. P., \& Leonard, P. B. (2010). Social work and restorative justice: Skills for dialogue, peacemaking, and reconciliation. New York: Oxford University Press.

Boy, A., \& Kulczycki, A. (2008). What we know about intimate partner violence in the Middle East and North Africa. Violence Against Women, 14(1), 53-70.

Braithwaite, J. (1989). Crime, shame and reintegration. Cambridge: Cambridge University Press.

Braithwaite, J., \& Strang, H. (2002). Restorative justice and family violence. In H. Strang \& J. Braithwaite (Eds.), Restorative Justice and Family Violence (pp. 1-22). Cambridge: Cambridge University Press.

Burkemper, B., \& Balsam, N. (2007). Examining the use of restorative justice practices in domesstic violence cases. Saint Louis University Public Law Review, 27(1), 121-264.

Busch, R. (2002). Domestic violence and restorative justice Initiatives: Who pays if we get it wrong. In H. Strang \& J. Braithwaite (Eds.), Restorative Justice and Family Violence (pp. 223-224). Cambridge: Cambridge University Press.

Castella, K. d., Platow, M. J., Wenzel, M., Okimoto, T., \& Feather, N. T. (2011). Retribution or Restoration? Anglo-Australian's views towards Domestic Violence Involving 
Muslim and Anglo-Australian Victims and Offenders. Psychology, Crime \& Law, 17(5), 403-420.

Cheon, A., \& Regehr, C. (2006). Restorative justice models in cases of intimate partner violence: Reviewing the evidence. Victims \& Offenders, 1(4), 369-394.

Coker, D. (2002). Tramsformative justice: Anti-subordination processes in case of domestic violence. In H. Strang \& J. Braithwaite (Eds.), Restorative Justice and Family Violence (pp. 128-152). Cambridge: Cambridge University Press.

Cunneen, C. (2003). Thinking Critically about Restorative Justice. In E. McLaughlin, R. Fergusson, G. Hughes \& L. Westmarland (Eds.), Restorative Justice: Critical Issues (pp. 182-194). London: Sage Publications.

Daly, K. (2012). Conferences and gendered violence: Practices, politics, and evidence. In E. Zinsstag \& I. Vangraechem (Eds.), Conferencing and Restorative Justice: International Practices and Perspectives (pp. 117-136). Oxford, UK: Oxford University Press.

Daly, K. (2016). What is restorative justice? Fresh answers to a vexed question. Victims and Offenders, 11(1), 9-29.

Daly, K., \& Hayes, H. (2001). Restorative Justice and Conferencing in Australia. Trends and Issues in Crime and Criminal Justice, 186, 1-6.

Daly, K., \& Stubbs, J. (2006). Feminist engagement with restorative justice. Theoretical Criminology, 10(1), 9-28.

Davies, J. (2009). Advocacy beyond leaving: Helping battered women in contact with current or former partners. San Francisco: Family Violence Prevention Fund.

Dissel, A., \& Ngubeni, K. (2003). Giving women their voice: Domestic violence and restorative justice in South Africa. Paper presented at the XIth International Symposium on Victimology, Stellenbosch, South Africa. 
Douglas, H. (2008). The criminal law's response to domestic violence: What's going on? Sydney Law Review, 30(3), 439-469.

Douki, S., Nacef, F., Belhadj, A., Bouasker, A., \& Ghachem, R. (2003). Violence against women in Arab and Islamic countries. Archives of Women's Mental Health, 6(3), 165 171.

Drost, L., Haller, B., Hofinger, V., van der Kooij, T., Lünnemann, K., \& Wolthuis, A. (2015). Restorative jutice in cases of domestic violcne: Best practice examples between increasing mutual understanding and awareness of specific protection needs (JUST/2013/JPEN/AG/4587) WS1. Comparative Report: Criminal Justice Programme 2013 with the European Commission Directorate-General Justice, Directorate B: Criminal Justice.

Eldoseri, H. M., \& Sharps, P. (2017). Risk Factors for Spousal Physical Violence Against Women in Saudi Arabia. $J$ Interpers Violence, 0886260517696861. doi: $10.1177 / 0886260517696861$

Erez, E. (2002). Domestic Violence and the Criminal Justice System: An Overview. Online Journal of Issues in Nursing, 7(1), 63-90.

Eriksson, L., \& Mazerolle, P. (2015). A Cycle of Violence? Examining Family-of-Origin Violence, Attitudes, and Intimate Partner Violence Perpetration. J Interpers Violence, 30(6), 945-964.

Faizi, N. (2001). Domestic violence in the Muslim community. Texas Journal of Women and the Law, 10(2), 209-230.

Flood, M., \& Pease, B. (2009). Factors influencing attitudes to violence against women. Trauma, violence \& abuse, 10(2), 125-142.

Frederick, L., \& Lizdas, K. C. (2009). The Role of restorative justice in the battered women's movement. In J. Ptacek (Ed.), Restorative Justice and Violence against Women. New York, NY: Oxford University Press. 
Garcia-Moreno, C., Jansen, H. A. F. M., Ellsberg, M., Heise, L., \& Watts, C. H. (2006). Prevalence of intimate partner violence: findings from the WHO multi-country study on women's health and domestic violence. The Lancet, 368, 1260-1269.

Ghafournia, N. (2017). Muslim women and domestic violence: Developing a framework for social work practice. Journal of Religion \& Spirituality in Social Work: Social Thought, 36(1-2), 146-163.

Goel, R. (2005). Sita's Trousseau: Restorative justice, domestic violence, and South Asian culture. Violence Against Women, 11(5), 639-665.

Goldblatt, H., Buchbinder, E., \& Eisikovits, Z. (2009). Between the professional and the private: the meaning of working with intimate partner violence in social workers' private lives. Violence Against Women, 15(3), 362-384.

Golub, S. (2003). Non-state justice systems in Bangladesh and the Philippines. Paper presented at the Conference on Justice System, Department for International Development, United Kingdom.

Gumz, E., \& Grant, C. (2009). Restorative justice: A systematic review of the social work literature. Families in Society: The Journal of Contemporary Social Services, 90(1), 119-126.

Haddad, L. G., Shotar, A., Younger, J. B., Alzyoud, S., \& Bouhaidar, C. M. (2011). Screening for Domestic Violence in Jordan: Validation of an Arabic Version of a Domestic Violence against Women Questionnaire. International journal of women's health, 3, 79-86.

Hadi, A. (2005). Women's productive role and marital violence in Bangladesh. Journal of family violence, 20(3), 181-189.

Hadley, M. L. (2006). Spiritual Foundations of Restorative Justice. In D. Sullivan \& L. Tift (Eds.), Handbook of Restorative Justice: A global perspective (pp. 174-187). Oxon: Routledge. 
Hadley, M. L. (Ed.). (2001). The spititual roots of restorative justice. Aalbany, NY: State University of New York.

Haj-Yahia, M. M. (1998). Beliefs About Wife Beating Among Palestinian Women: The Influence of Their Patriarchal Ideology. Violence Against Women, 4(5), 533-558.

Haj-Yahia, M. M. (2010). Palestinian Physicians' misconceptions about and approval of wife abuse. J Interpers Violence, 25(3), 416.

Hamid, R. M. (2015). Domestic Violence in Muslim Communities. In A. J. Johnson (Ed.), Religion and Men's Violence Against Women (pp. 319-342): Springer New York.

Haqqi, A. R. A. (2015). Criminal punishment and persuit justice in Islamic law. International Journal of Technical Research and Applications, 15(15), 1-10.

Harris, N. (2006). Reintegrative shaming, shame, and criminal justice. Journal of Social Issues, 62(2), 327-346.

Hascall, S. C. (2012). Restorative justice in Islam: should Qisas be considered a form of restorative justice. Berkeley Journal of Middle Eastern \& Islamic Law, 4(1), 35-78.

Hassouneh-Phillips, D. S. (2001). "Marriage is Half of Faith and the Rest is Fear Allah" Marriage and Spousal Abuse Among American Muslims. Violence Against Women, 7(8), 927-946.

Hayden, A., Gelsthorpe, L., Kingi, V., \& Morris, A. (2014). Introduction. In A. Hayden, L. Gelsthorpe, V. Kingi \& A. Morris (Eds.), A restorative approach to family violence: Changing track. (pp. 1-6). Surrey, UK: Ashgate.

Holtmann, C. (2016). Christian and Muslim Immigrant women in the Canadian Maritimes: Considering their strengths and vulnerabilities in responding to domestic violence. Studies in religion/Sciences religieuses, 45(3), 397-414.

Hopkins, C. Q., Koss, M. P., \& Bachar, K. J. (2004). Applying restorative justice to ongoing intimate violence: problems and possibilities. Saint Louis University Public Law Review, 23, 289-311. 
House, M., \& Hargovan, H. (2011). Restorative justice and domestic violence: some exploratory thoughts. Agenda: Empowering Women for Gender Equity, 19(66), 48-56.

Hovell, M. F., Seid, A. G., \& Liles, S. (2006). Evaluation of a police and social services domestic violence program: Empirical evidence needed to inform public health policies. Violence Against Women, 12(2), 137-159.

Human Rights Watch. (1999). Crime or custom: violence against women in Pakistan. New York, NY: Human Rights Watch.

Hunter, R. C. (2006). Narratives of domestic violence. The Sydney Law Review, 28(4), 733776.

Husain, A. (2017). Islam in the 21st century: Challenges and opportunities for social work with Muslims. Journal of Religion \& Spirituality in Social Work: Social Thought, $36(1-2), 1-5$.

Ibrahim, N., \& Abdalla, M. (2010). A Critical examination of Qur'an 4:34 and Its relevance to intimate partner violence in Muslim families. Journal of Muslim mental health, $5(3), 327-349$.

Islam, M. J., Baird, K., Mazerolle, P., \& Broidy, L. (2017). Exploring the influence of psychosocial factors on exclusive breastfeeding in Bangladesh. Archives of Women's Mental Health, 20(1), 173-188.

Islam, M. J., Broidy, L., Baird, K., \& Mazerolle, P. (2017a). Exploring the associations between intimate partner violence and delayed entry to prenatal care: Evidence from a cross-sectional study in Bangladesh. Midwifery, 47, 43-55.

Islam, M. J., Broidy, L., Baird, K., \& Mazerolle, P. (2017b). Intimate partner violence around the time of pregnancy and postpartum depression: The experience of women of Bangladesh. PLoS One, 12(5), e017621. 
Islam, M. J., Mazerolle, P., Broidy, L., \& Baird, K. (2017). Exploring the prevalence and correlates associated with intimate partner violence during pregnancy in Bangladesh. $J$ Interpers Violence. doi: 10.1177/0886260517730029

Islam, M. J., Rahman, M., Broidy, L., Haque, S. E., Saw, Y. M., Duc, N. H. C., Haque, M. N., Rahman, M. M., Islam, M. R., \& Mostofa, M. G. (2017). Assessing the link between witnessing inter-parental violence and the perpetration of intimate partner violence in Bangladesh. BMC Public Health, 17(1), 183.

Islamic Fiqh Academy (IFA). (2009). Domestic violence. Retrieved 24 August 2015, from http://pamelageller.com/2011/05/oic-fatwa-on-domestic-violence-and-the-rights-ofwomen-in-islam-beat-your-wife.html/

Jayasundara, D., Nedegaard, R., Sharma, B., \& Flanagan, K. (2014). Intimate partner violence in Muslim communities. Arts and Social Sciences Journal, s1, 1-12.

Jewkes, R. (2002). Intimate partner violence: causes and prevention. The Lancet, 359(9315), 1423-1429.

Johnson, M. P. (2006). Conflict and control: Gender symmetry and asymmetry in domestic violence. Violence Against Women, 12(11), 1003-1018.

Kendall-Tackett, K. A. (2007). Violence against women and the perinatal period: The impact of lifetime violence and abuse on pregnancy, postpartum, and breastfeeding. Trauma, violence \& abuse, 8(3), 344-353.

Kingi, V. M., Paulin, J., \& Porima, L. (2008). Review of the Delivery of Restorative Justice in Family Violence Cases by Providers funded by Ministry of Justice, Wellington, New Zealand: Crime and Justice Research Centre, Victoria, University of Wellington

Kohn, L. S. (2010). What's so funny about peace, love, and understanding? restorative justice as new paradigm for domestic violence intervention. Seton Hall Law Review, 40, 517 595. 
Krantz, G. (2002). Violence against women: a global public health issue! Journal of epidemiology and community health, 56(4), 242-243.

Liebmann, M., \& Wootton, L. (2010). Restorative justice and domestic violence/abuse. Cafdiff: The Home Office Crime Reduction Unit for Wales.

Loeffler, C. H., Prelog, A. J., Unnithan, N. P., \& Pogrebin, M. R. (2010). Evaluating shame transformation in group treatment of domestic violence offenders. International Journal of Offender Therapy and Comparative Criminology, 54(4), 517-536.

Malik, O. A. (2014). The roles of Masjid in matrimonial dispute Settlement (MDS) in Nigeria: an assessment of the Shar'iah concept of Sulh. Paper presented at the The Global Summit on Education GSE 2014, Kuala Lumpur, Malaysia.

Maranlou, S. (2015). Access to justice in Iran: Women, perceptions, and reality. New York: Cambridge University Press.

Marder, I. (2014). Opportunities to use restorative justice in the Moroccan criminal justice process. Washington, DC: Search for Common Ground.

Mburia-Mwalili, A., Clements-Nolle, K., Lee, W., Shadley, M., \& Yang, W. (2010). Intimate Partner Violence and Depression in a Population-Based Sample of Women: Can Social Support Help? J Interpers Violence, 25(12), 2258-2278.

McCold, P. (2003). A survey of assessment research on mediation and conferencing. In L. Walgrave (Ed.), Repositioning restorative justice (pp. 67-120). Uffculme, , UK: Willan Publishing.

Miller, S. L., \& Iovanni, L. (2013). Using restorative justice for gendered violence: success with a postconviction model. Feminist Criminology, 8(4), 247-268.

Mills, L. G., Maley, M. H., \& Shy, Y. (2009). Circulos De Paz and the promise of peace: Restorative justice meets intimate violence. N.Y.U Review of law \& Social Change, $133,127-152$. 
Moran, G. (2015). Access to Justice in Bangladesh - Situation Analysis: Summary Report. Dhaka, Bangladesh: Ministry of Law, Justice and Parliamentary Affairs, Government of the People's Republic of Bangladesh.

Morris, A. (2002). Children and Family Violence: Restorative Messages from New Zealand. In H. Strang \& J. Braithwaite (Eds.), Restorative Justice and Family Violence (pp. 89107). Cambridge: Cambridge University Press.

Morris, A., \& Gelsthorpe, L. (2003). Re-visioning men's violence against female partners. In E. McLaughlin, R. Fergusson, G. Hughes \& L. Westmarland (Eds.), Restorative Justice: Critical Issues (pp. 127-140). London: SAGE Publications.

Morris, T., \& Trammell, R. (2011). Formal and informal justice and punishment: Urban law and rural mediation rituals in Yemen. Race and Justice, 1(2), 131-153.

Naeem, F., Irfan, M., Zaidi, Q. A., Kingdon, D., \& Ayub, M. (2008). Angry wives, abusive husbands: relationship between domestic violence and psychosocial variables. Women Health Issues, 18(6), 453-462.

Okon, E. E. (2014). Hudud Punishments in Islamic Criminal Law. European Scientific Journal, 10(14), 227-238.

Pavlich, G. C. (2005). Governing paradoxes of restorative justice. London: GlassHouse Press.

Pelikan, C. (2010). On the Efficacy of Victim-Offender-Mediation in Cases of Partnership Violence in Austria, or: Men Don't Get Better, but Women Get Stronger: Is It Still True?: Outcomes of an Empirical Study. European Journal on Criminal Policy and Research, 16(1), 49-67.

Pew Research Center. (2011). The future of the global Muslim population: Projections for 2010-2030 Pew Research Center's Forum on Religion \& Public Life. Washington, D.C.: Pew Research Center.

Presser, L., \& Gaarder, E. (2000). Can restorative justice reduce battering ? Some preliminary considerations. Social Justice, 27(1), 175-195. 
Ptacek, J., \& Loretta, F. (2009). Restorative Justice and Intimate Partner Violence. Harrisburg, PA.

Qafisheh, M. M. (2012). Restorative justice in the Islamic penal law: a contribution to the global system. International Journal of Criminal Justice Sciences, 7(1), 487-507.

Rahami, M. (2007). Islamic restorative traditions and their reflections in the post revolutionary criminal justice system of Iran. European Journal of crime, criminal law and criminal justice, 15(2), 227-248.

Ross, L. E. (2012). Religion and intimate partner violence: A double-edge sword. Catalyst: A social justice forum, 2(3), 3-12.

Rubin, P. (2009). A community of one's own? When women speak to power about restorative justice. In J. Ptacek (Ed.), Restorative Justice and Violence against Women (pp. 79102). New York, NY: Oxford University Press.

Saffari, M., Arslan, S. A., Yekaninejad, M. S., Pakpour, A. H., Zaben, F. A., \& Koenig, H. G. (2017). Factors Associated With Domestic Violence Against Women in Iran: An Exploratory Multicenter Community-Based Study. $J$ Interpers Violence, 0886260517713224. doi: 10.1177/0886260517713224

Stubbs, J. (2002). Domestic violence and women's safety: Feminist challenges to restorative justice. In H. Strang \& J. Braithwaite (Eds.), Restorative Justice and Family Violence (pp. 42-61). Cambridge: Cambridge University Press.

Stubbs, J. (2004). Restorative justice, domestic violence and family violence. Australian Domestic \& Family Violence Clearinghouse(9), 1-24.

Stubbs, J. (2007). Beyond apology?: Domestic violence and critical questions for restorative justice. Criminology and Criminal Justice, 7(2), 169-187.

Sunan Abu Dawud. (n.d.). Kitab Al-Nikah. Retrieved 24 August, 2015, from http://sunnah.com/abudawud/12 
Tisdall, M., Farmer, S., Robinson, M., Wells, A., \& McMaster, K. (2007). Review of the use of restorative justice in family violence cases in the Rotorua district. Wellington, New Zealand New Zealand Ministry of Justice.

Trabold, N., Waldrop, D. P., Nochajski, T. H., \& Cerulli, C. (2013). An exploratory analysis of intimate partner violence and postpartum depression in an impoverished urban population. Social work in health care, 52(4), 332-350.

Umbreit, M. S. (1993). Crime victims and offenders in Mediation: An emerging area of social work practice. Social Work, 38(1), 69-73. doi: 10.1093/sw/38.1.69

UNFPA. (2003). Male attitude toward violence against women in Bangladesh. Dhaka, Bangladesh.

Uthman, O. A., Moradi, T., \& Lawoko, S. (2009). The independent contribution of individual-, neighbourhood-, and country-level socioeconomic position on attitudes towards intimate partner violence against women in sub-Saharan Africa: a multilevel model of direct and moderating effects. Social Science \& Medicine, 68(10), 18011809.

Van Wormer, K. (2003). Restorative justice: a model for social work practice with families. Families in Society: The Journal of Contemporary Social Services, 84(3), 441-448.

Van Wormer, K. (2006). The case for restorative justice: A crucial adjunct to the social work curriculum. Journal of Teaching in Social Work, 26(3-4), 57-69.

Wenzel, M., Okimoto, T. G., Feather, N. T., \& Platow, M. J. (2008). Retributive and restorative justice. Law and human behavior, 32(5), 375-389.

Wong, D. S. W., \& Wing Lo, T. (2011). The recent development of restorative social work practices in Hong Kong. International Social Work, 54(5), 701-716.

Wood, W. R., \& Suzuki, M. (2016). Four Challenges in the Future of Restorative Justice. Victims \& Offenders, 11(1), 149-172. 
World Health Organization (WHO). (2013). Global and regional estimates of violence against women: Prevalence and health effects of and non-partner sexual violence. Geneva, Switzerland: World Health Organization. 